\title{
PERANCANGAN SISTEM INFORMASI PENDATAAN KARYAWAN PADA PERUSAHAAN JASA BERBASIS WEB
}

\author{
Harfizar $^{1}$ \\ Khozin Yuliana $^{2}$ \\ Muh Afiffudin ${ }^{3}$ \\ Dosen STMIK Raharja ${ }^{1,2}$ \\ STMIK Raharja Jurusan Sistem Informasi ${ }^{3}$ \\ Jl. Jendral Sudirman No. 40, Modernland, Tangerang ${ }^{1,2,3}$ \\ E-mail : harfizar@raharja.info ${ }^{1}$, khozin@ $\underline{\text { raharja.info }}^{2}$, afiffudin@raharja.info $^{3}$
}

\begin{abstract}
ABSTRAK
Kebutuhan akan informasi serta pengambilan keputusan secara cepat dan tepat merupakan hal mutlak yang harus dipenuhi oleh sebuah perusahaan. Demikian halnya dengan Pada Perusahaan yang bergerak dalam bidang penyedia jasa tentang kebandaradaraan. Menghadapi persaingannya didunia bisnis, perusahaan tersebut dituntut untuk selalu berinovasi dalam pelayanan informasi serta peningkatan kualitas operasional perusahaan, Oleh karena itu, maka media informasi yang tepat adalah website.Untuk menangani masalah pendataan karyawan pada perusahaan jasa kota Tangerang. Sistem ini dibuat menggunakan Metode penelitian yang digunakan adalah dengan melakukan penelitian berupa metode observasi pada perusahaan jasa kota Tangerang. Metode wawancara langsung kepada pegawai Personalia staff umum pada perusahaan jasa kota Tangerang. pengamatan dan studi pustaka untuk memperoleh data melalui arsip - arsip yang terdapat pada perusahaan jasa kota Tangerang. Dengan bahasa pemrograman PHP dan HTML. Untuk saat ini permasalahan yang dihadapi pada perusahaan jasa kota Tangerang.Program Aplikasi Pendataan Karyawan Pada Perusahaan Jasa Kota Tangerang. yang belum ada, Maka diciptakanlah sebuah program aplikasi pendataan karyawan ini yang diharapkan akan menjadi media penyampaian informasi yang berguna dan bermanfaat untuk dapat meningkatkan kualitas perusahaan serta nilai yang kompetitif bagi Perusahaan, khususnya para karyawan/karyawati Staff Pada Perusahaan jasa Kota Tangerang.
\end{abstract}

Kata Kunci : Website, Sistem Pendataan Karyawan

\section{ABSTRACT}

The need for information and decision making quickly and accurately is an absolute thing that must be fulfilled by a company. Similarly with the Company engaged in the field of service providers about the independence. Facing the competition in the business world, the company is required to always innovate in information services and improving the company's operational quality, Therefore, the right media information is the website. To handle the problem of employee data collection at Tangerang city service company. This system is made using the research method used is to conduct research in the form of observation methods at the service company Tangerang city. Direct interview method to Personnel staff of general staff at Tangerang city service company. Observation and literature study to obtain data through archives contained in the Tangerang city service company. With PHP and HTML programming language. For now the problems faced by Tangerang city service company. Employee Data Application Program At Tangerang City Service Company. Which has not existed, then created an application program data collection of these employees are expected to be a useful and useful information delivery media to improve the company's quality and competitive value for the Company, especially the employees / employee Staff At Tangerang City service company.

Keywords: Website, Employee Data Collection System

Vol.3 No.2 - Agustus 2017 


\section{PENDAHULUAN}

Perkembangan tekhnologi informasi yang semakin meningkat seiring dengan adaptasi zaman mampu menunjang berbagai permintaan kebutuhan dan informasi bagi pengguna. tekhnologi komputer merupakan sistem informasi yang mendukung suatu organisasi untuk mengoptimalkan aktifitasnya dalam mencapai tujuan tertentu, kebutuhan akan suatu sistem komputerisasi pada zaman ini mencakup hampir disegala bidang. Perkembangan teknologi informasi terus berkembang sesuai dengan kebutuhan dan kegiatan organisasi dalam menghadapi persaingan yang begitu ketat. Setiap perusahaaan sangat membutuhkan sistem komputerisasi yang akurat, cepat, efisien serta up to date dalam kegiatan dan informasinya. Namun dalam kenyataan hal tersebut tidak sesuai dengan keinginan dan harapan yang hendak dicapai, dikarenakan kurang atau terbatasnya sistem informasi yang digunakan dari pengaplikasian komputer.

Kemajuan teknologi khususnya teknologi informasi, dimana informasi tersebut tentu saja tidak bisa diserap dengan hanya mengandalkan cara-cara atau perangkat-perangkat yang masih kuno dan serba manual, maka dari itu kegunaan komputer sangat penting dalam memberikan suatu solusi dan merupakan alat bantu yang cukup baik dalam memperbaiki sistem yang belum optimal.

Sistem komputerisasi merupakan salah satu alternatif yang paling banyak diminati dan digunakan oleh organisasi/perusahaan. Dalam sistem pendataan karyawan. Sistem komputerisasi mampu membantu dan mempermudah dalam menginput, memproses, menghasilkan bahkan menyimpan data.

Pencatatan pendataan karyawan merupakan salah satu faktor penting dalam pengelolaan sumber daya manusia. Informasi yang mendalam dan terperinci mengenal seseorang karyawan secara lengkap. Namun dalam hal ini seiring dengan berjalannya sistem ternyata masih dapat kekurangan-kekurangan terhadap sistem yang sedang berjalan. Didalam pencatatan pendataan karyawandalam suatu perusahaan, informasi setiap tahunnya kurang begitu lengkap, tidak ada laporan pelatihan, status kerja,dan lamanya berkerja karyawan, sehingga informasi pada laporan tidak akurat.

\section{Rumusan Masalah} berikut:

Berdasarkan latar belakang di atas, maka penulis merumuskan beberapa masalah sebagai

1. Bagaimana sistem pendataan karyawan pada PERUSAHAAN Tangerang yang berjalan saat ini?

2. Apakah system pendataan karyawan pada PERUSAHAAN Tangerang yang berjalan saat ini sudah efektif dan efisien?

3. Bagaimana aplikasi yang diusulkan dapat menciptakan proses laporan yang cepat dan akurat?

Ruang lingkup penelitian dibatasi pada masalah yang terkait dengan program aplikasi pendataan karyawan yang sedang berjalan saat ini, yang meliputi sistem pendataan pribadi, data keluarga, aktivitas lain, dan pengalaman kerja. 


\section{LANDASAN TEORI}

\section{KONSEP DASAR SISTEM Definisi Sistem}

Berikut ini adalah pengertian Definisi Informasi dari beberapa ahli, yaitu:

Menurut Tohari Hamim (2014:7), "Informasi adalah data yang telah diproses sedemikian rupa sehingga memiliki arti yang lebih bermanfaat bagi penggunanya"

Menurut Bambang Hartono (2013:15), "Informasi pada dasarnya adalah sehimpunan data yang telah diolah menjadi sesuatu yang memiliki arti dan kegunaan lebih luas".

Maimunah, Lusyani Sunarya, dkk dalam jurnal CCIT (2012:57)," Informasi adalah data yang telah diolah menjadi sebuah bentuk yang lebih berarti bagi penerimanya dan bermanfaat dalam mengambil suatu keputusan".

Berdasarkan beberapa pendapat yang dikemukakan di atas dapat di tarik kesimpulan bahwa "Informasi adalah fakta yang telah diolah dengan cara tertentu yang menggambarkan suatu kejadian nyata untuk diolah agar dapat dipahami dan digunakan dalam pengambilan suatu keputusan".

\section{Struktur Informasi}

Struktur Informasi adalah hubungan antar data (antar-record), yang dapat berupa hubungan Hierarkis atau hubungan asosiatif: ( Bambang Hartono, 2013:86).

1. Hubungan Hierarkis adalah hubungan berjenjang yang bersifat "atasan-bawahan". Contoh: record tentang gaji atau record tentang hutang seorang karyawan merupakan "bawahan" dari record tentang karyawan tersebut.

2. Hubungan Asosiatif adalah hubungan antar data (antar-record) hal yang terjadi karena kesesama isi atau nilai dari data (record) tersebut. Misalnya kesamaan dalam hal tempat kerja.

\section{Karakter Sistem}

Ada sepuluh karakteristik sistem yang dikemukakan oleh: Bambang Hartono, (2013:9)

1. Komponen Sistem (Componen System)

Bagian-bagian atau elemen-elemen, yang dapat berupa benda atau manusia, berbentuk nyata atau abstrak, dan disebut subsistem.

2. Penghubung antarbagian (Interface)

Suatu yang bertugas menjembatani satu bagian dengan bagian lain, dan memungkinkan terjadinya interaksi/komunikasi antarbagian.

3. Batas (Boundary)

Sesuatu yang membedakan antara satu sistem dengan sistem atau sistem-sistem lain.

4. Lingkungan (Enviroment)

Segala sesuatu yang berada diluar sistem dan dapat bersifat menguntungkan atau merugikan sistem yang bersangkutan. 
5. Masukan (Input)

Sesuatu yang merupakan bahan diolah atau diproses oleh sistem.

6. Mekanisme Pengolahan (Processimg)

Perangkat dan prosedur untuk mengubah masukan menjadi keluaran dan menampilkannya.

7. Keluaran (Output)

Berbagai macam bentuk hasil atau produk yang dikeluarkan dari pengolahan.

8. Tujuan (Goal/objective)

Sesuatu atau keadaan yang ingin dicapai oleh sistem, baik dalam jangka pendek maupun jangka panjang.

9. Sensor dan Kendali (Sensor \& Control)

sesuatu yang bertugas memantau dan mengifornasikan perubahan-peruabahan di dalam lingkungan dan dalam diri sistem kepada sistem.

10. Umpan Balik (Feedback)

Informasi tentang perubahan-perubahan lingkungan dan perubahan-perubaha (penyimpanan) dalam diri sistem mengembalikannya ke kondisi normal.

\section{Klasifikasi Sistem}

Sistem dapat diklasifikasikan dari beberapa sudut pandang diantaranya: ( Rohmat Taufiq, 2013:8)

1. Sistem Abstrak (Abstract System) dan Sistem Fisik (Physical System).

Sistem abstrak merupakan sistem yang berupa pemikiran atau ide-ide yang tidak tampak secara fisik. Misalnya sistem teologi, yaitu sistem yang berupa pemikiran-pemikiran hubungan anatara manusia dengan Tuhan. Sistem fisik merupakan sistem yang ada secara fisik. Misalnya sistem komputer, sistem produksi, dan sistem transportasi.

2. Sistem Dapat Dipastikan dan Sistem Tidak Dapat Dipastikan.

Sitem dapat dipastikan merupakan suatu sistem yang input proses dan output sudah ditentukan sejak awal. Sudah dideskripsikan dengan jelas apa inputnya seperti apa. Sedangkan sistem tidak dapat dipastikan atau sistem probabilistik merupakan sebuah sistem yang belum terdefinisi dengan jelas salah satu dari input-proses-output atau ketiganya belum terdefinisi dengan jelas.

3. Sistem Tertutup dan Sistem Terbuka.

Sistem terututp dan sistem terbuka yang membendakan adalah ada faktor-faktor yang mempengaruhi dari luar sistem atau tidak, jika tidak ada faktor-faktor yang mempengaruhi dari luar iti bisa disebut dengan sistem tertutup tapi jika ada pengaruh komponen dari luar disebut sistem terbuka.

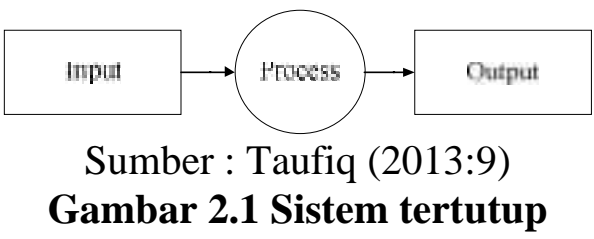




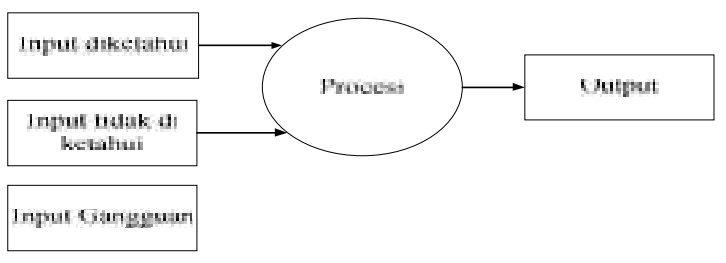

Sumber : Taufiq (2013:9)

\section{Gambar 2.2.Sistem Tertutup}

4. Sistem Manusia dan Sistem Mesin

Sistem manusia dan sistem mesin merupakan sebuah klasifikasi sistem jika dipandang dari pelakunya. Pada zaman yang semakin global dan semuanya serba maju ini tidak semua sistem dikerjakan oleh manusia tapi beberapa sistem dikerjakan oleh mesin tergantung dari kebutuhannya. Sistem manusia adalah suatu sistem yang proses kerjanya dilakukan oleh manusia sebagai contoh pelaku sistem organisasi, sistem akademik yang masih manual, transaksi jual beli dipasar tradisional,dll. Adapun sistem mesin merupakan sebuah sistem yang proses kerjanya dilakukan oleh mesin, sebagai contoh sistem motor, mobilm mesin industri, dan lain-lain,

5. Sistem Sederhana dan Sistem Kompleks

Sistem dilihat dari tingkat kekomplekan masalahnya dibagi menjadi dua yaitu sistem sederhana dan sistem kompleks. Sistem sederhana merupakan sistem yang sedikit subsistemnya dan komponen-komponennya pun sedikit. Adapun sistem kompleks adalah sistem yang banyak sub-sub sistemnya sehingga proses dari sistem itu sangat rumit.

6. Sistem bisa beradaptasi dan sistem tidak bisa beradaptasi

Sistem yang bisa beradaptasi terhadap lingkungannya merupakan sebuah sistem yang mampu bertahan dengan adanya perubahan lingkungan. Sedangkan sistem yang tidak bisa beradaptasi dengan lingkungan merupakan sebuah sistem yang tidak mampu bertahan jika terjadi perubahan lingkungan.

7. Sistem Alamiah (Natural System) dan Sistem Buatan Manusia (Human Made System) Sistem alamiah adalah sisten yang terjadi melalui proses alam, tidak dibuat manusia. Misalnya sistem tata surya. Sistem buatan manusia adalah sistem yang melibatkan interaksi manusia dengan mesin yang disebut human machine system. Misalnya sistem telekomunikasi. Sistem Sementara dan Sistem Selamanya. Sistem sementara dan sistem selamanya merupakan klasifikasi sistem jika dilihat dari pemakainya. Sistem sementara merupakan sebuah sistem yang dibangun dan digunakan untuk waktu sementara, sebagai contoh sistem pemilihan presiden, setelah proses pemillihan presiden sudah tidak dipakai lagi dan untuk pemilihan lima tahun mendatang kemungkinan sistem selamanya merupakan sistem yang dipakai untuk jangka panjang atau digunakan selamanya, misalnya sistem pencernaan.

\section{Struktur Informasi}

Struktur Informasi adalah hubungan antar data (antar-record), yang dapat berupa hubungan Hierarkis atau hubungan asosiatif: ( Bambang Hartono, 2013:86).

1. Hubungan Hierarkis adalah hubungan berjenjang yang bersifat "atasan-bawahan". Contoh: record tentang gaji atau record tentang hutang seorang karyawan merupakan "bawahan" dari record tentang karyawan tersebut. 
2. Hubungan Asosiatif adalah hubungan antar data (antar-record) hal yang terjadi karena kesesama isi atau nilai dari data (records) tersebut. Misalnya kesamaan dalam hal tempat kerja.

\section{Definisi Sistem Informasi}

Berikut ini adalah pengertian Definisi Sistem Informasi dari beberapa ahli, yaitu :

I Putu Agus Eka Pratama (2014:10) menyatakan bahwa: Sistem Informasi merupakan bagian dari empat bagian utama. Keempat bagian utama tersebut mencakup perangkat lunak (software), perangkat keras (hardware), infrastruktur,dan Sumber Daya Manusia (SDM) yang terlatih. Keempat bagian utama ini saling berkaitan untuk menciptakan sebuah sistem yang dapat mengolah data menjadi informasi yang bermanfaat.

Menurut Taufiq Rohmat (2013:17), Sistem Informasi adalah kumpulan dari sub-sub sistem yang saling terintegrasi dan berkolaborasi untuk menyelesaikan masalah tertentu dengan cara mengolah data dengan alat yang namanya komputer sehingga memiliki nilai tambah dan bermanfaat bagi pengguna.

Berdasarkan beberapa pendapat diatas peneliti dapat menarik kesimpulan bahwa sistem informasi adalah komponen-komponen yang membentuk sistem yang menghasilkan suatu informasi yang berfungsi sebagai penyedia informasi atau laporan.

\section{Komponen-komponen Sistem Informasi}

Komponen-komponen yang terdapat didalam semua jenis sistem informasi mencakup tujuh poin. Berikut ketujuh komponen tersebut beserta dengan penjelasan masing-masing: ( I Putu Agus Eka Pratama, 2014:11)

1. Input (Masukan)

Sebuah informasi berasal dari data yang telah diolah dan diverifikasi sehingga akurat, bermanfaat, dan memiliki nilai. Komponen input ini berfungsi untuk menerima semua input (masukan) dari pengguna, inputan yang diterima dalam bentuk data. Data ini berasal dari satu maupun beberapa buah sumber.

2. Output (Keluaran)

Sebuah sistem informasi akan menghasilkan keluaran (Output) berupa informasi. Komponen output berfungsi untuk menyajikan hasil akhir ke pengguna sistem informasi.

3. Software (Perangkat Lunak)

Komponen software (perangkat lunak) mencakup semua perangkat lunak yang digunakan didalam sistem informasi. Adanya komponen perangkat lunak ini membatu sistem informasi didalam menjalankan tugasnya dan untuk dapat dijalankan sebagainya mestinya.

\section{Hardware (Perangkat Keras)}

Komponen hardware ( perangkat keras) mencakup semua perangkat komputer yang digunakan secara fisik didalam sistem informasi, baik dikomputer server maupun dikomputer client.

5. Database (Basis Data)

Komponen basis data berfungsi untuk menyimpan semua data dan informasi kedalam satu atau beberapa tabel. Setiap tabel memiliki field masing-masing. Setiap tabel memiliki fungsi penyimpanan masing-masing, serta atar tabel dapat juga terjadi relasi (hubungan). 
6. Kontrol dan Prosedur

Kontrol dan prosedur adalah dua buah komponen yang menjadi satu. Komponen kontrol berfungsi untuk mencegah terjadinya beragam gangguan dan ancaman terhadap data dan informasi yang ada didalam sistem informasi, termasuk juga sistem informasi itu sendiri beserta fisiknya (dalam hal ini komputer server).

7. Tekonologi dan Jaringan Komputer

Komponen terakhir didalam sistem informasi ini, yaitu teknologi jaringan komputer, memegang peranan terpenting untuk sebuah sistem informasi. Komponen teknologi mengatur software, hardware, database, kontrol dan prosedur, input dan output.

\section{PENGERTIAN KINERJA KARYAWAN}

Suatu organisasi perusahaan didirikan karena mempunyai tujuan tertentu yang ingin dan harus dicapai. Dalam mencapai tujuannya setiap organisasi di pengaruhi perilaku organisasi. Salah satu kegiatan yang paling lazim di lakukan dalam organisasi adalah kinerja karyawan, yaitu bagaimana ia melakukan segala sesuatu yang berhubungan dengan sesuatu pekerjaan atau peranan dalam organisasi.

Pengertian kinerja atau performance merupakan gambaran mengenai tingkat pencapaian pelaksanaan suatu program kegiatan atau kebijakan dalam mewujudkan sasaran, tujuan visi dan misi organisasi yang di tuangkan melalui perencanaan strategi suatu organisasi.Arti kata kinerja berasal dari taka-kata job performance dan di sebut juga actual performance atau prestasi kerja atau prestasi sesungguhnya yang telah di capai oleh seseorang kariyawan. Moeheriono ( 2012: 69)

\section{LITERATURE REVIEW}

Banyak penelitian yang sebelumnya (literature review) dilakukan mengenai pembahasan tentang perancangan sistem pendataan karyawan pada perusahaan jasa berbasis web. pada dunia industri saat ini. Dalam melakukan pendataan karyawan ini perlu dilakukan studi pustaka untuk dijadikan sebagai bahan acuan untuk memperkuat hasil penelitian dengan cara mengindetifikasikan metode yang pernah dilakukan, perancangan penelitian sebelumnya yang memiliki korelasi yang seimbang dengan sistem pendataan karyawan pada perusahaan jasa. Beberapa literature review yang didapatkan diantaranya adalah sebagai berikut :

1. Penelitian yang dilakukan oleh Kasmadi fauzi (2013). Program studi sistem informasiSekolah tinggi manajemen informatika dan komputerSTMIK u'budiyah indonesiaBanda aceh. Pelaporan penggunaan yang berjudul"sistem informasi data karyawan pada PT. Pos indonesia (persero) banda acehBerbasis web"Perkembangan ilmu pengetahuan dan teknologi pada saat ini mempunyaiperanan yang sangat penting, salah satunya dibidang komputer, banyak instansi pemerintahan ataupun swasta yang sudah menggunakan sistem komputerisasi untuk proses pengolahan data. Metode penelitian yang digunakan adalah dengan melakukan penelitian lapangan berupa wawancara, pengamatan dan studi pustaka untuk memperoleh data dan informasi yang diperlukan dalam penelitian. Tujuan pembahasan ini adalah untuk mengetahui sistem pengolahan data karyawan yang dilakukan oleh PT. Pos Indonesia (Persero) Banda Aceh. Dengan menggunakan fasilitas 
komputerisasi dalam mengolah data maka akan berdampakbaik bagi para karyawan yang ingin mengetahui data-data karyawan. Sistem informasi data karyawan pada PT. Pos Indonesia (Persero) Banda Aceh yang akan dirancang untuk mempermudah dalam proses pengolahan data para karyawan terutama data karyawan, data bagian, data jabatan untuk mendapatkan informasi yang lebih cepat dan akurat.

2. Penelitian sekripsi yang dilakukan oleh Rizal sylvana (2014). Program studi d-iii manajemen informatika sekolah tinggi manajemen informatika dan komputer STMIK u'budiyah indonesia banda aceh. Pelaporan penggunaan yang berjudul'Perancangan sistem informasi kepegawaian STMIK u'budiyah indonesia menggunakan php mysql".Sistem Informasi kepegawaian pada U'Budiyah Indonesiaadalah sebuah sistem yang mengelola data pegawai U'Budiyah Indonesia, sistem ini akan mengolah serta memberikan infomasi terhadap data pegawai yang ada dengan cepat serta mempermudahkan dokumentasi terhadap data-data yang baru, dimana untuk sebelumnya pada U'Budiyah Indonesia belum memiliki suatu sistem yang dapat mengolah data dengan efisien dan efektif. Dengan dibuatnya sistem informasi ini maka laporan-laporan yang berhubungan dengan data pegawai dapat diperoleh dengan cepat. Sistem ini menggunakan bahasa pemrograman PHP, serta Xampp 1.5.4. Dimana hasil akhir yang diharapkan berupa Sistem Informasi pegawai pada U'Budiyah Indonesia berbasis web yang mencakup pendataan data pegawai, data izin seminar, data izin sekolah, data izin cuti, data seminar, data sekolah, data cuti data bidang dan data jabatan.

3. Penelitian jurnal yang dilakukan oleh R. Prasetyo Agung Nugroho, Purwanto (2015). Program studi STMIK AMIKOM Yogyakarta. Pelaporan penggunaan yang berjudul'Rancangan Sistem Pendukung Keputusan Penerimaan Pegawai Menggunakan Metode Profil Matching'. Peranserta tenaga kerja sebagaiSumber Daya Manusia (SDM) merupakan sebuah roda penggerak bagi kemajuan perusahaan.Demi memajukan perusahaan maka diperlukan tenaga kerja yang dapat pula bekerja dengan kemampuan maksimal, handal dan berkompeten dalam menjalankan aktifitas didalam perusahaan.Olehkarena itu,SDMharus diseleksidengan tepat agar mendapatkan tenaga kerja yang berkualitas.Makadalam pemilihan atauseleksitenaga kerja seringkali terjadi polemik, karena ada kemungkinan penilaian subyektif terhadap seseorangsehingga prosestidak berjalan dengansemestinya. PT. Bank Rakyat Indonesia merupakan sebuah perusahaan yang bergerak dalam jasa keuangan dan memiliki banyak sekali bagian didalamnya dan masing-masing bagian memiliki tugas serta tanggung jawab yang berbeda-beda tetapi berjalan sebagai satu kesatuan untuk terus memajukan perusahaan.Maka ditiap bagian tersebut perlu memilik SDM yang handal guna menyelaraskan tujuan untuk terus menjadi perusahaan yang terbaik. Dalam penerimaan karyawan ada beberapa faktor yang perlu dipertimbangkan, yaitumelalui pengujian berbagai macam tes yangmeliputi penilaian tentang,kecepatan kerja,target kerja,kedisiplinan dalam bekerja, pelayanan kepadapelanggan, team work, kejujuran dan ketelitian. 


\section{PEMECAHAN MASALAH}

\section{Rancangan sistem yang di usulkan}

Usulan perosedur yag baru ini bertujuan untuk mempermudah sistem saat ini agar permasalahan yang timbul dapat diminimalkan dan mendapatkan hasil yang optimal. Prosedur yang diusulkan yaitu aplikasi pendataan karyawan berbasis web (web based).

Ada beberapa prosedur yang baru harus dilakukan oleh admin untuk pendataan karyawanPada. PERUSAHAAN Tangerang, yaitu:

1. Username

Masukan nama untuk mengidentifikasikan seseorang pada sistem komputer.

2. Password

Admin akan memasukan kata sandi untuk mengidentifikasikan pada sebuah web.

3. Prosedur Pendataan Karyawan

Admin akan membuka website aplikasi untuk input pendataan karyawan baru di PT. Jakadara Aircraft Services.

4. Prosedur Penilaian Karyawan

Admin akan membuka website aplikasi dan input manual dari data setiap departemen di PT. Jakadara Aircraft Services.

Untuk menggambarkan prosedur yang baru aplikasi pendataan karyawan ini, pada penggambaran kali ini digunakan use case diagram, activity diagram, sequence diagram, class diagram dan statechart diagram. yaitu sebagai berikut:

\section{Diagram Rancangan Sistem}

Untuk menganalisa sistem yang diusulkan, pada penelitian ini digunakan program visual paradigm for uml 6.4 enterprise edition untuk menggambarkan use case diagram, activity diagram, class diagram, sequence diagram, dan statechart diagram.

\section{Use Case Diagram Yang Diusulkan}

Use case diagram digunakan untuk menggambarkan hubungan interaksi antara sistem dan pemakai admin 


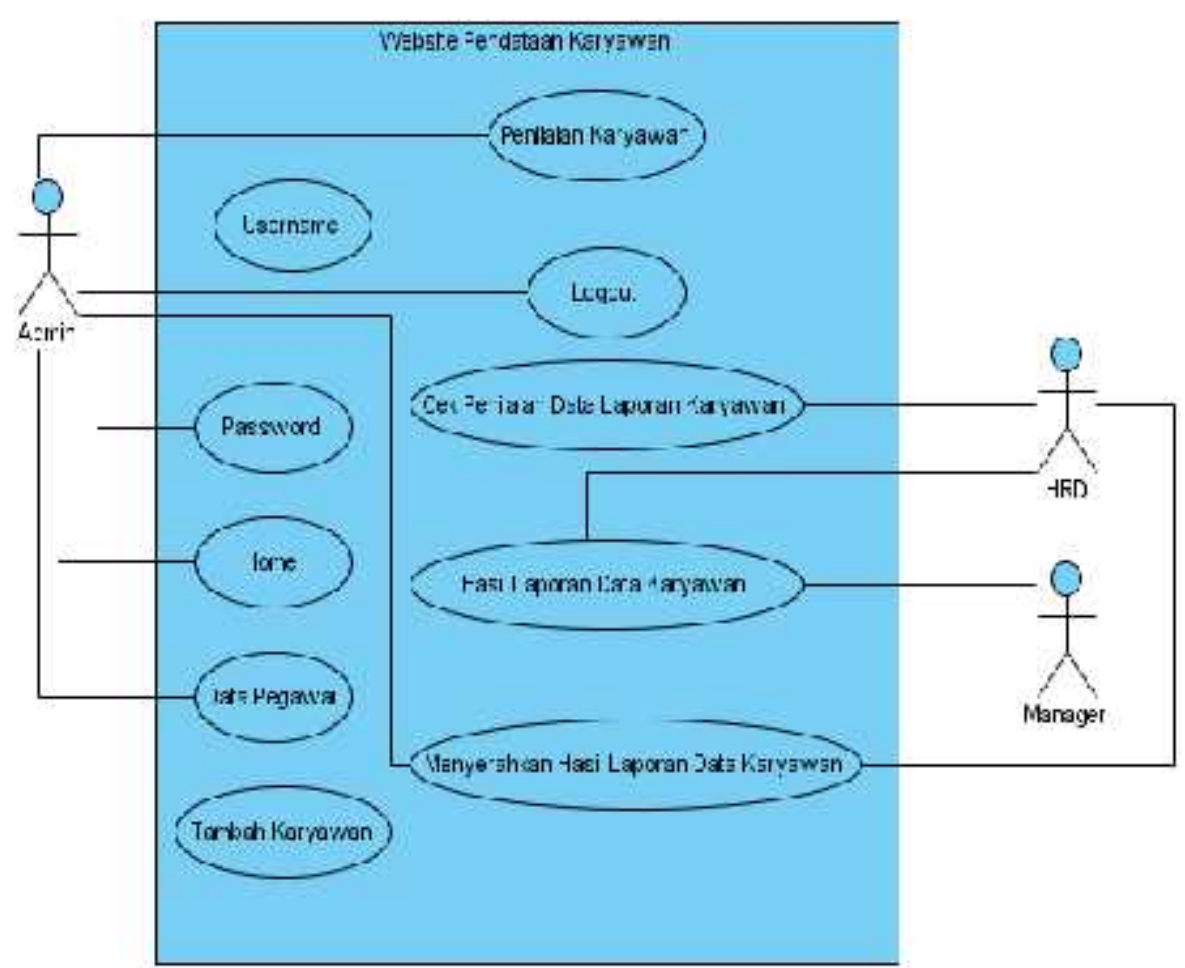

Gambar 1. Use casediagram yang diusulkan untuk web Pendataan karyawan

Berdasarkan gambar 1use case diagram yang diusulkan terdapat:

1. Terdapat 1 sistem yang mencakup seluruh kegiatan aplikasi

2. Terdapat 3 actor yang melakukan kegiatan, diantaranya: admin, HRD dan manager.

3. Terdapat10use case yang dilakukan oleh actor.

\section{Activity Diagram Yang Diusulkan}

Activity diagram menggambarkan berbagai alur aktivitas dalam sistem yang dirancang, bagaimana masing-masing alur berawal, decision yang mungkin terjadi, dan bagaimana mereka berkhir. Activity diagram juga dapat menggambarkan proses paralel yang mungkin terjadi pada beberapa eksekusi. 


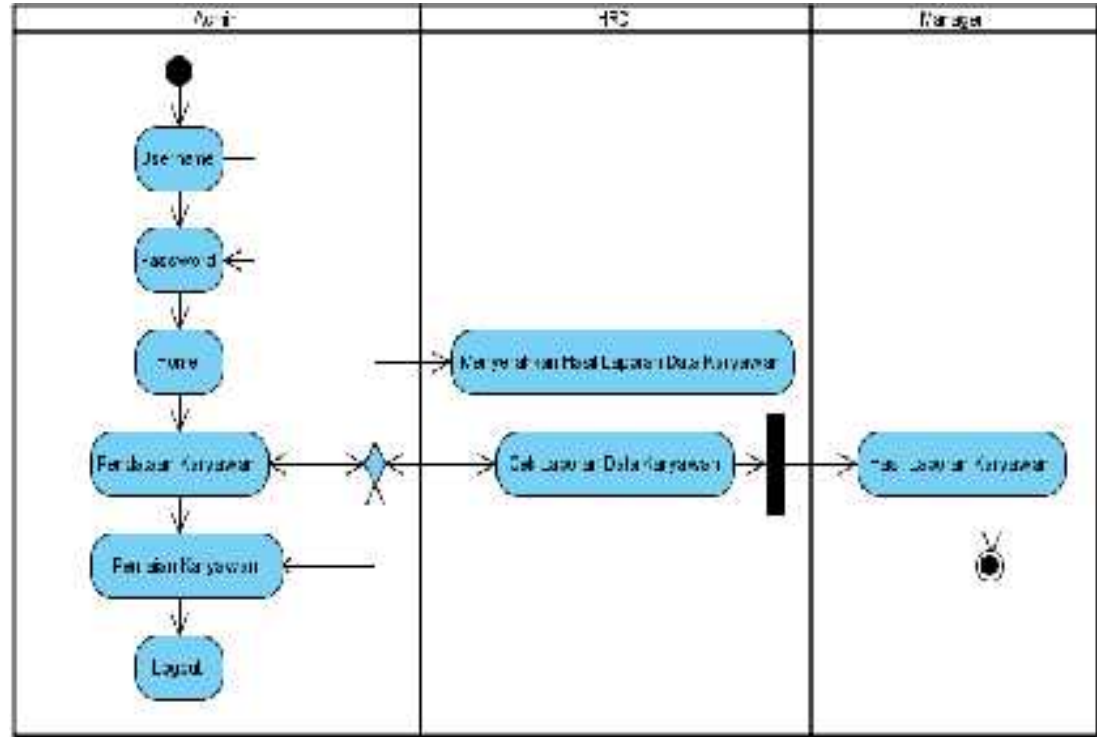

Gambar 2. Activity diagram yang diusulkan untuk admin, HRD dan manager

Berdasarkan gambar 2activity diagram yang diusulkan terdapat:

a. Terdapat 3 initial node, objek yang diawali.

b. Terdapat 3 vertical swimline, untuk menghubungkan seluruh activity.

c. Terdapat9action,sistem yang mencerminkan eksekusi dari suatu aksi.

d. Terdapat 1joinnode, objek yang menggabungkan seluruh action.

e. Terdapat 1 activityfinal node, objek yang di akhiri.

\section{Class Diagram Yang Diusulkan}
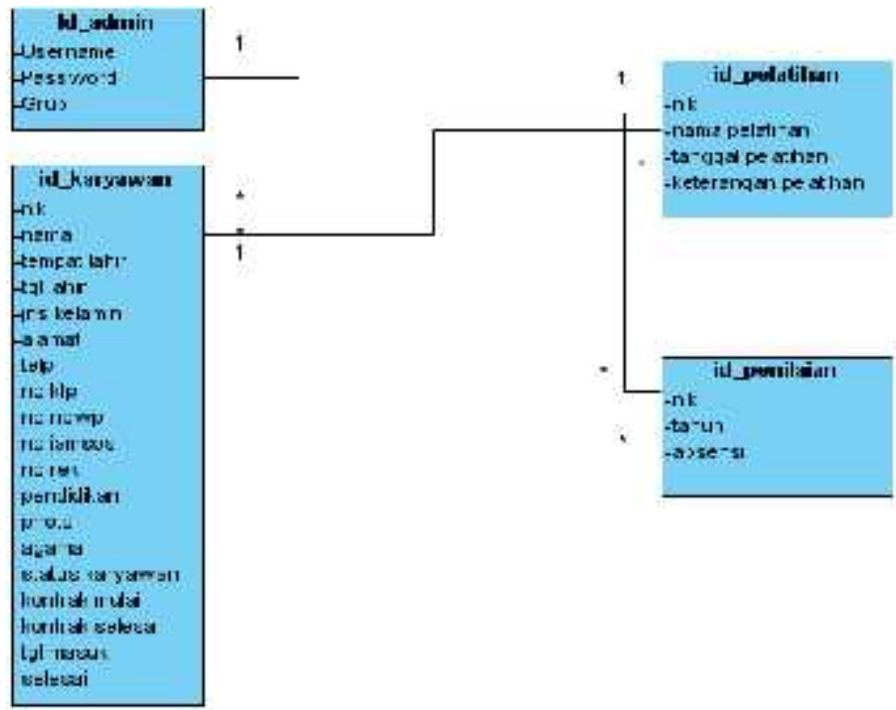

Gambar 3. Class diagram yang diusulkan webPendataan karyawan

Berdasarkan gambar 3class diagram yang diusulkan terdapat: 
a. Terdapat 4class, himpunan dari objek-objek yang berbagi atribut serta operasi yang sama.

b. Terdapat 4association, digunakan untuk memodelkan relasi di antara objek.

\section{Sequence Diagram Yang Diusulkan}

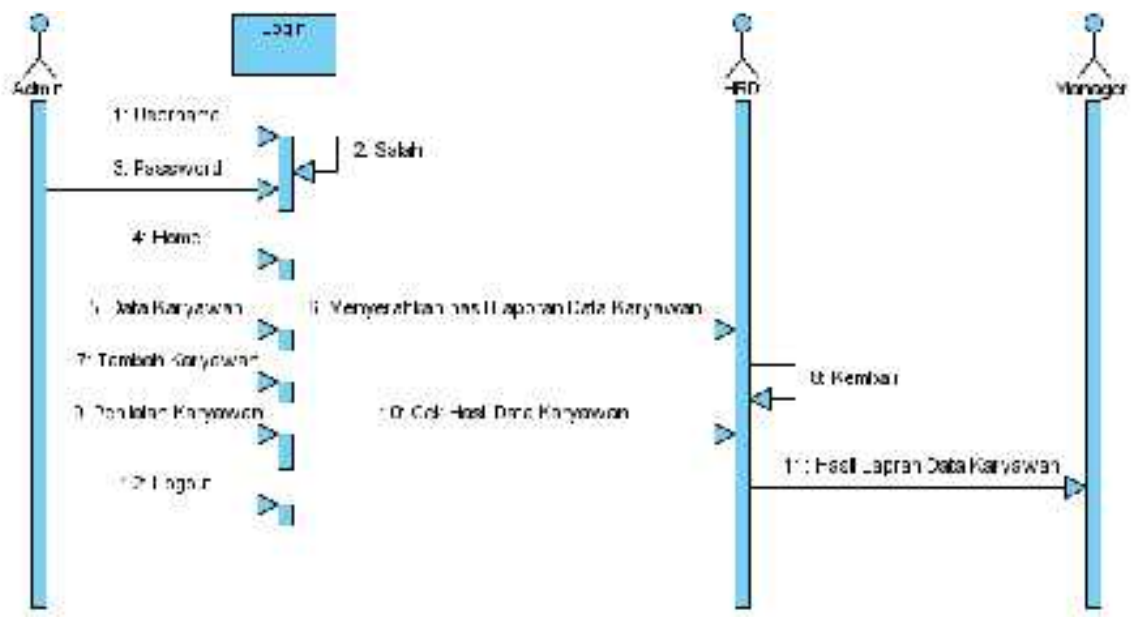

Gambar 4. Sequence diagram admin, HRD dan Manager yang diusulkan webpendataan karyawan

Berdasarkan gambar 4 sequence diagram admin diatas yang diusulkan:

1. Terdapat 3actor yaitu admin.

2. Terdapat 12lifeline.

3. Terdapat 1 message.

State Chart Diagram yang Diusulkan

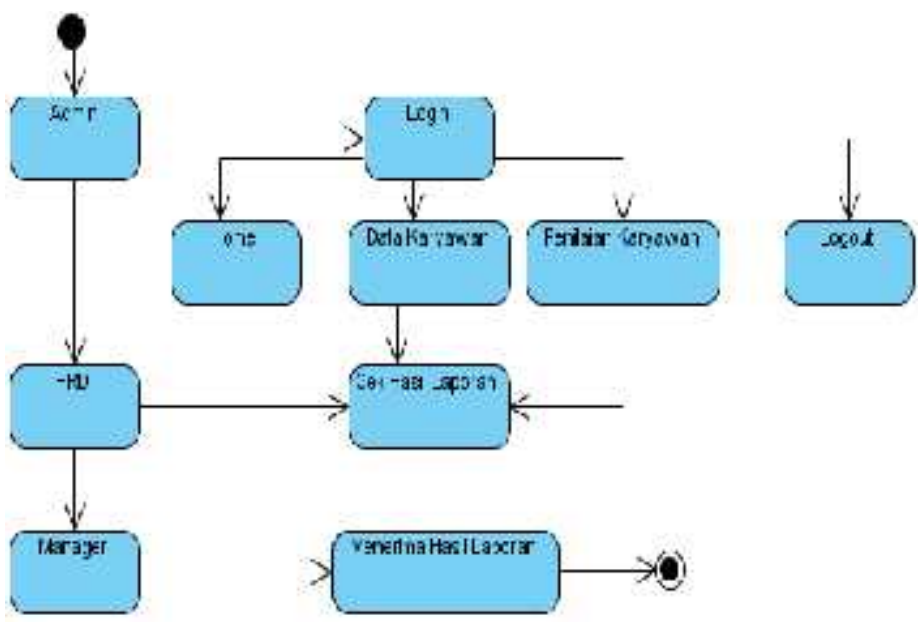

Gambar 5. State chart diagram admin, HRD dan manager 
Berdasarkan gambar 4.8. state diagram penduduk diatas yang diusulkan:

1. Terdapat 1 initial pseudo state mengawali objek.

2. Terdapat 10 nilai atribut dan nilai link pada suatu waktu tertentu, yang dimiliki oleh suatu objek tersebut.

3. Terdapat 1 final state mengakhiri objek.

\section{Rancangan Spesifikasi Basis Data}

Rancangan basis data yang diusulkan terdapat beberapa tabel yang diambil dari database. Selanjutnya menuju tahapan spesifikasi basis data yang akan dijelaskan nama file, isi, key, panjang record. Berikut adalah spesifikasi basis data yang diusulkan adalah sebagai berikut:

1. Nama tabel :tbl_admin

Media : : hardisk

Organisasi file : index

Isi :Id_Admin+

User_Name+

Password+

GrubPrimary key :ID_ADMIN

Panjang record : 65

Tabel 1. Struktur tabel_admin

\begin{tabular}{|c|l|c|c|c|}
\hline $\begin{array}{c}\text { N } \\
\text { o }\end{array}$ & $\begin{array}{l}\text { Nama } \\
\text { Field }\end{array}$ & $\begin{array}{c}\text { Type } \\
\text { Data }\end{array}$ & $\begin{array}{c}\text { Field } \\
\text { Size }\end{array}$ & $\begin{array}{c}\text { Ketera } \\
\text { ngan }\end{array}$ \\
\hline 1 & $\begin{array}{l}\text { Id_ad } \\
\text { min }\end{array}$ & Int & 3 & $\begin{array}{l}\text { Primar } \\
\text { Key }\end{array}$ \\
\hline 2 & $\begin{array}{l}\text { User_n } \\
\text { ame }\end{array}$ & $\begin{array}{c}\text { Varcha } \\
r\end{array}$ & 10 & \\
\hline 3 & $\begin{array}{l}\text { Passw } \\
\text { ord }\end{array}$ & $\begin{array}{c}\text { Varcha } \\
r\end{array}$ & 32 & \\
\hline 4 & Grub & $\begin{array}{c}\text { Varcha } \\
r\end{array}$ & 20 & \\
\hline
\end{tabular}

2. Nama tabel : tbl_data karyawan

Media : : hardisk

Organisasifile : index

Isi : id_nik+nama

+tempatlahir+jnskelamin+alamat+telp+

Noktp+nonpwp+nojamsos+norek+pendidikan+Photo+

agama+statuskaryawan+kontrakmulai+kontrakselesai+ tanggalmasuk+status

Primary key : Id_status

Panjang record : 382 
Tabel 2.Struktur tabel_data karyawan

\begin{tabular}{|c|l|c|c|l|}
\hline No & \multicolumn{1}{|c|}{ Nama Field } & $\begin{array}{c}\text { Type } \\
\text { Data }\end{array}$ & $\begin{array}{c}\text { Field } \\
\text { Size }\end{array}$ & Keterangan \\
\hline 1 & Nik & varchar & 8 & \\
\hline 2 & Nama & varchar & 25 & \\
\hline 3 & Tempat lahir & varchar & 50 & Foreign Key \\
\hline 4 & Tgl lahir & Date & & \\
\hline 5 & Jns kelamin & varchar & 1 & \\
\hline 6 & Alamat & varchar & 100 & \\
\hline 7 & Telp & varchar & 12 & \\
\hline 8 & No ktp & varchar & 25 & \\
\hline 9 & No npwp & varchar & 25 & \\
\hline 10 & No jamsostek & varchar & 25 & \\
\hline 11 & No rekening & varchar & 25 & \\
\hline 12 & Pendidikan & varchar & 50 & \\
\hline 13 & Photo & Text & & \\
\hline 14 & Agama & varchar & 25 & \\
\hline 15 & $\begin{array}{l}\text { Status } \\
\text { karyawan }\end{array}$ & varchar & 10 & \\
\hline 16 & Kontak mulai & Date & & \\
\hline 17 & Kontrak selesai & Date & & \\
\hline 18 & Tanggal masuk & Date & & \\
\hline 19 & Status & Int & 1 & Primary Key \\
\hline
\end{tabular}

3. Nama tabel :tbl_pelatihan
Media
: hardisk

Organisasi file

: index

Isi

:id_pelatihan+

nik+namapelatihan+tanggalpelatihan+

keteranganpelatihan

Primary key : id_pelatihan

Panjang record : $: 97$

Tabel 3.Struktur tabel_pelatihan

\begin{tabular}{|c|l|c|c|l|}
\hline No & \multicolumn{1}{|c|}{ Nama Field } & $\begin{array}{c}\text { Type } \\
\text { Data }\end{array}$ & Field Size & Keterangan \\
\hline 1 & id_pelatihan & Int & 11 & Primary key \\
\hline 2 & nik & Int & 11 & \\
\hline 3 & nama pelatihan & varchar & 50 & \\
\hline 4 & tanggal pelatihan & date & & Foreign Key \\
\hline 5 & $\begin{array}{l}\text { keterangan } \\
\text { pelatihan }\end{array}$ & varchar & 25 & \\
\hline
\end{tabular}


4. Nama tabel : tbl_penilaian

Media

: hardisk

Organisasi file

: index

Isi

: id_penilaian+

nik+tahun+absensi

Primary key : id_penilaian

Panjang record : :48

Tabel 4Struktur tabel_penilaian

\begin{tabular}{|c|l|c|c|l|}
\hline No & Nama Field & $\begin{array}{c}\text { Type } \\
\text { Data }\end{array}$ & Field Size & Keterangan \\
\hline 1 & id_penilaian & Int & 11 & Primary Key \\
\hline 2 & nik & Int & 11 & \\
\hline 3 & tahun & Int & 11 & Foreign Key \\
\hline 4 & absensi & Varchar & 15 & \\
\hline
\end{tabular}

\section{IMPLEMENTASI}

\section{Rancangan Tampilan Program Login}
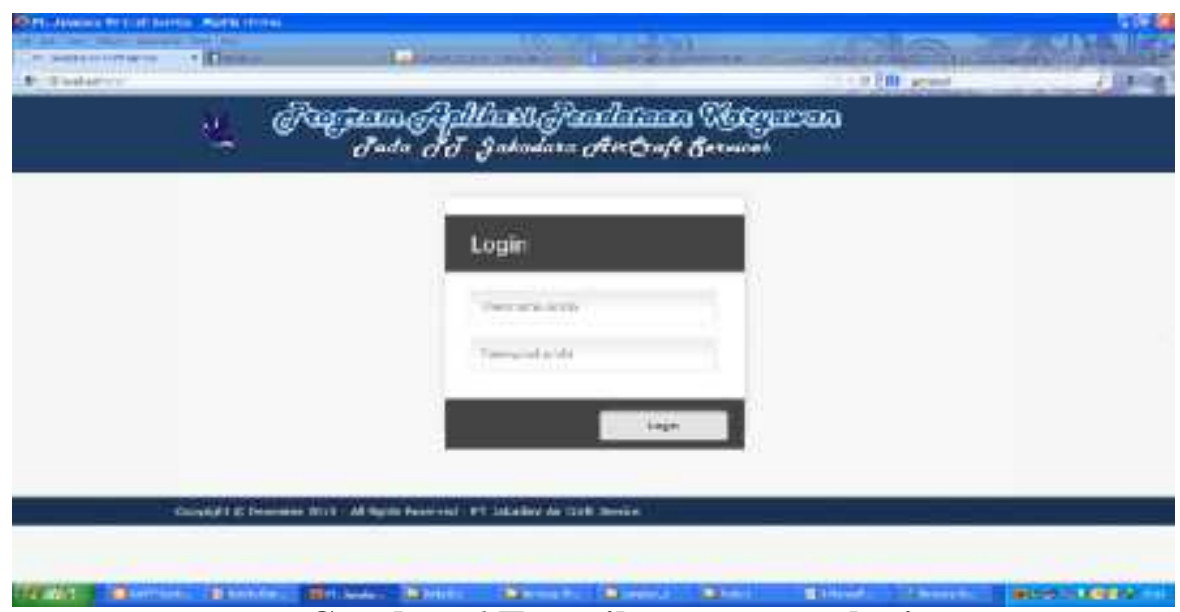

\section{Gambar 6 Tampilan program login}

Keterangan rancangan tampilan program login:

Username : Masukkan nama untuk mengidentifikasikan seseorang padasistem komputer.

Password :Admin akan memasukan kata sandi untuk mengidentifikasikan pada sebuah web.

Login : Verifikasi login berhasil. 


\section{Rancangan Tampilan Program Home}

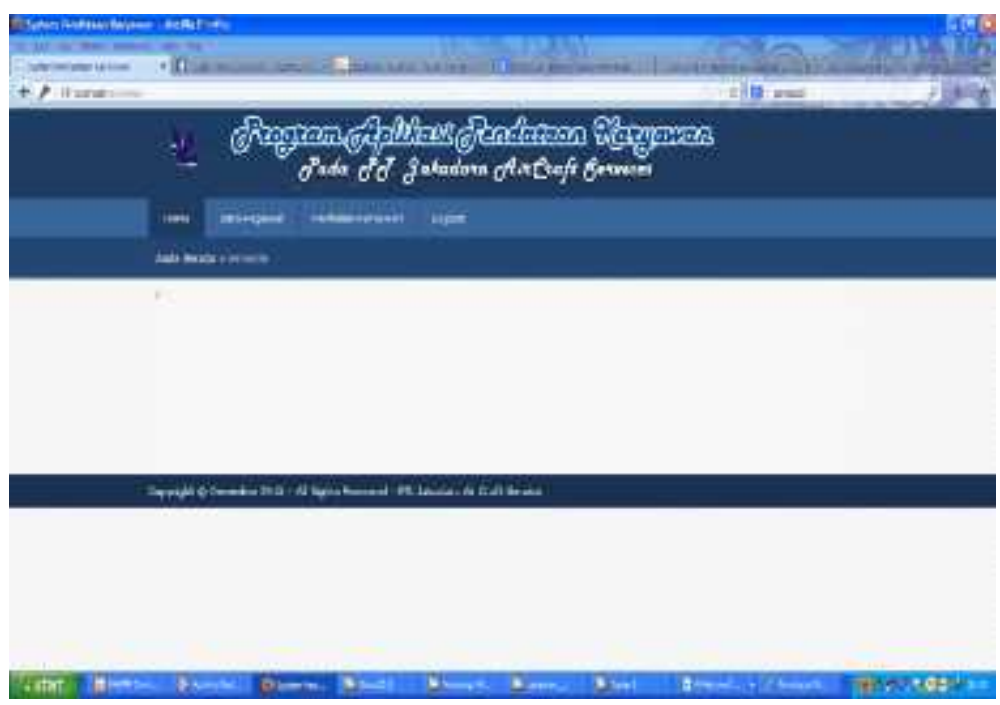

Gambar 7 Tampilan program home

Keterangan rancangan tampilan program home:

Home: Sebagai halaman pertama atau pembuka yang menampilkan ucapkan selamat datang bagi user.

\section{Rancangan Tampilan Program Data Karyawan}

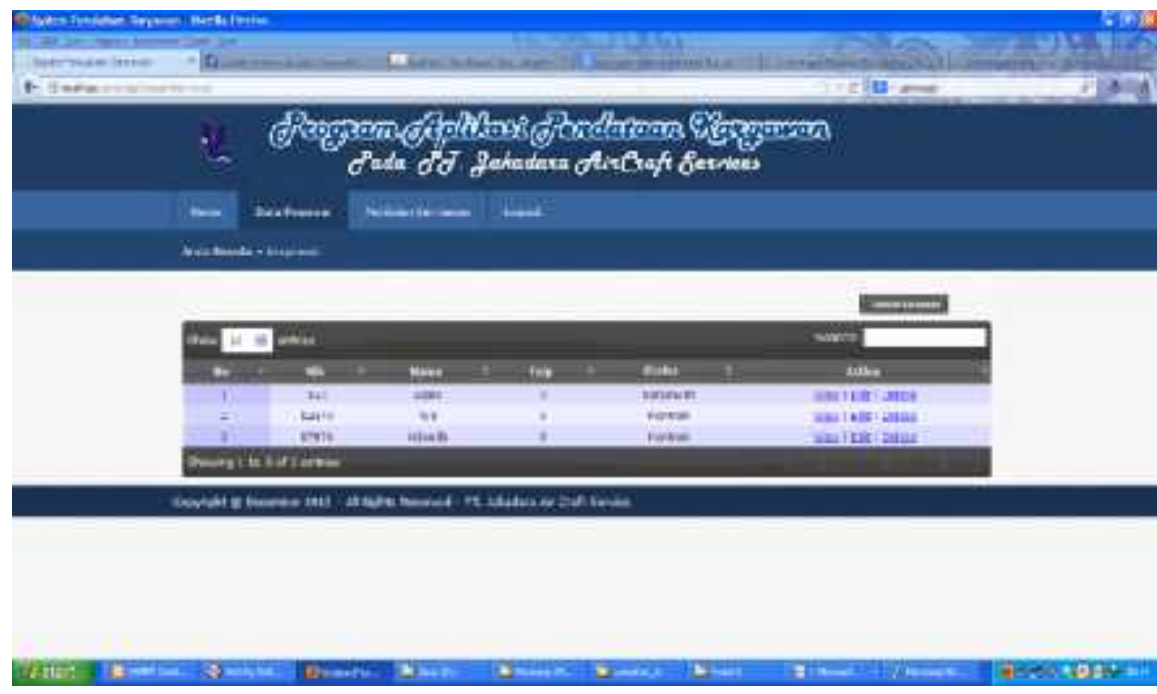

Gambar 8 Tampilan program data karyawan

Keterangan rancangan tampilan program data karyawan:

Data karyawan :menampilkan semua data karyawan 


\section{Rancangan Tampilan Program Tambah Karyawan}

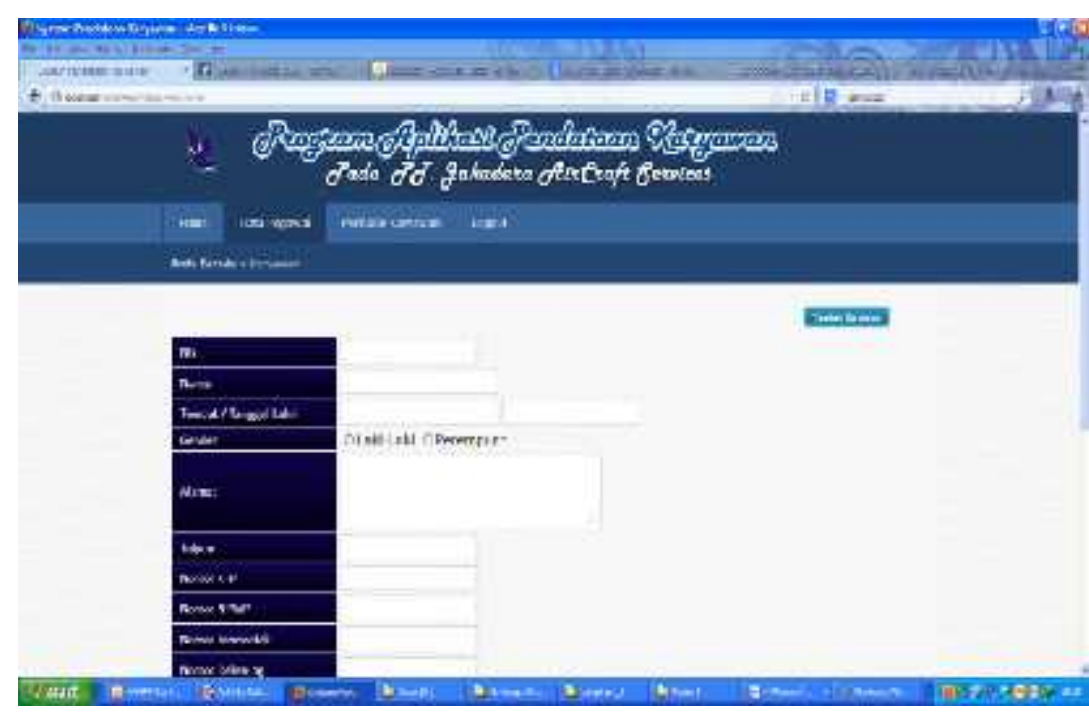

Gambar 9 Tampilan program tambah karyawan

Keterangan rancangan tampilan program tambah karyawan:

Tambah karyawan : Memasukkan data karyawan baru.

\section{Rancangan Tampilan Program Penilaian Karyawan}

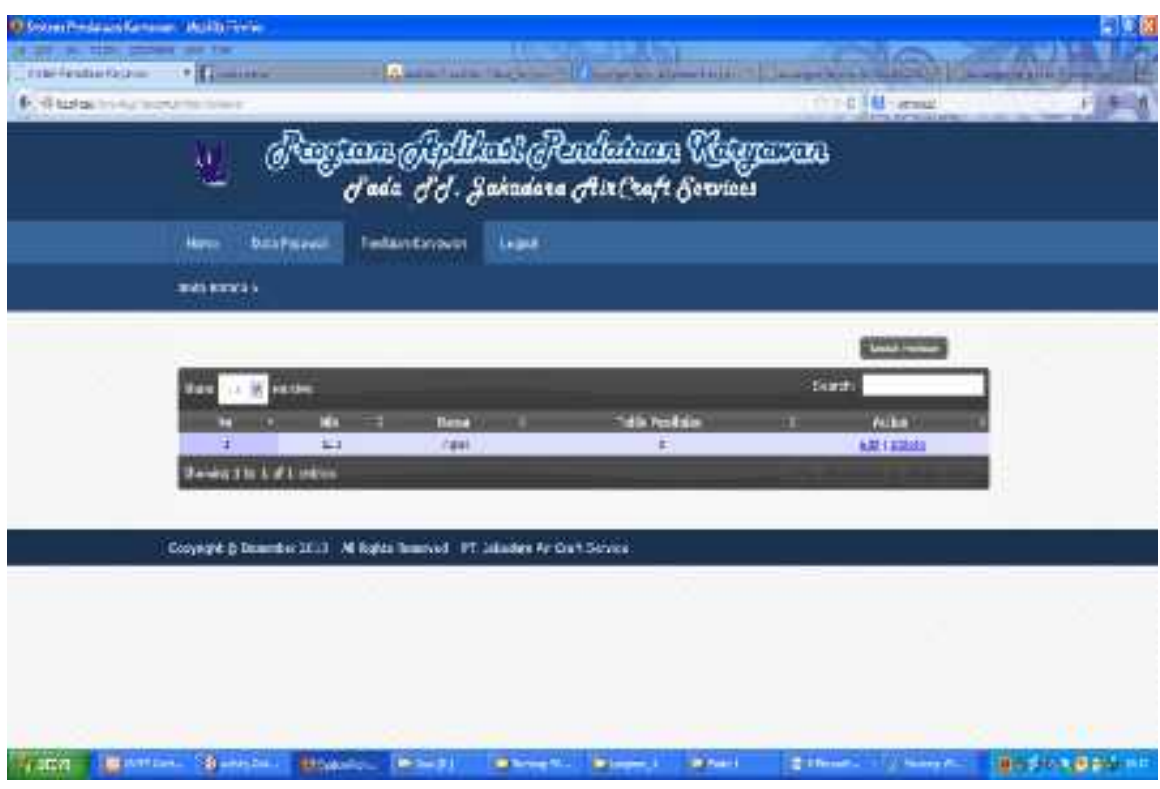

Gambar 10 Tampilan program penilaian karyawan

Keterangan rancangan tampilan program penilaian karyawan:

Penilaian karyawan: Memasukkan data absensi karyawan dan pelatihan karyawan. 


\section{KESIMPULAN}

Berdasarkan uraian pada bab-bab sebelumnya, serta hasil analisa yang dilakukan oleh penulis mengenai Pembuatan Program Absensi Karyawan Pada PT JAKADARA Aircraft Services Tangerang, maka penulis dapat memberikan kesimpulan sebagai berikut:

1. Sistem pendataan karyawan pada PERUSAHAAN masih menggunakan formulir dan belum memenuhi kriteria yang dibutuhkan oleh Admin dan Pengguna / User.

2. Sistem Pendataan pada PERUSAHAAN yang berjalan membutuhkan waktu yang cukup lama sehingg kurang efisien dan efektif.

3. Program Pendataan Karyawan yang diusulkan mampu membantu menangani Sistem Pendataan Karyawan PadaPERUSAHAAN untuk pengimputan tidak membutuhkan waktu yang lama dan mengetahui data para karyawan secara cepat dan akurat.

\section{DAFTAR PUSTAKA}

[1] Bambang Hartono. 2013. Sistem Informasi Manajemen Berbasis Komputer. Jakarta: Rineka Cipta.

[2] Taufiq, Rohmat. 2013. Sistem Informasi Manajemen, Konsep Dasar, Analisa Dan Metode Pengembangan. Yogyakarta : Graha Ilmu.

[3] Suprihadi, Rini Kartika Hudiono, Lina Sinatra Wijaya. 2013. Rancang Bangun Sistem Jejaring Klaster Berbasis Web Menggunakan Metode Model View Controller. Vol.6 No.3 Mei 2013 ISSN: 1978-8282 STMIK Raharja.

[4] Tohari Hamim. Analisis Serta Perancangan Sistem Informasi Melalui Pendekatan UML. Yogyakarta: Andi Offset. 2014.

[5] Maimunah, Lusyani Sunarya, Nina Larasti.2012. Media Company ProfileSebagai Sarana Penunjang Informasi dan Promosi .Jurnal CCIT Vol.5No.3-Mei 2012.Tangerang:Perguruan Tinggi Raharja.

[6] Pratama, I Putu Agus Eka. 2014. Sistem Informasi dan Implementasinya. Bandung: BI Obses.

[7] Moeheriono. 2012. Pengukuran kinerja berbasis kopetensi. Jakarta: Raja Grafindo Persada.

[8] Fauzi, Kasmadi. 2013. Sistem Informasi Data Karyawan Pada PT. POS Indonesia (Persero) Banda Aceh Berbasis Web. Banda aceh : STMIK U'Budiyah Indonesia.

[9] Rizal, sylvana. 2014. Perancangan Sistem Informasi Kepegawaian STMIK U'Budiyah Indonesia Banda Aceh.

[10] R. Prasetyo Agung Nugroho, Purwanto. 2015. Rancangan Sistem Pendukung Keputusan Penerimaan Pegawai Menggunakan Metode Profil Matching. STMIK AMIKOM Yogyakarta 